\title{
Vaccination Studies Against COVID-19 Agent: Current Status
}

\section{COViD-19 Etkenine Karşı Aşı Çalışmaları: Mevcut Durum}

\author{
(1) Sevilay HINTISTAN1ㄴ, io Aysun KAZAK²
}

${ }^{1}$ Karadeniz Technical University Faculty of Health Sciences, Department of Internal Medicine, Nursing, Trabzon, Turkey

${ }^{2}$ Gümüşhane University Health Services Vocational School, Department of Medical Services and Technical Dialysis Program, Gumushane,

Turkey

\begin{abstract}
The emergence of the new pathogenic viral strains is a constant threat to global health. The latest new coronavirus strain coronavirus-2019 (COVID-19) is the best-known example of this. COVID-19, caused by the severe acute respiratory syndrome-CoV-2 virus has quickly spread around the globe. The applications of drug and vaccine practices, and the identification of potential candidates are of high importance against this pandemic. On healthy adults, a proper evaluation of potential vaccines in parallel with vaccination studies on animal models and an enlargement of production capacity will benefit minimum risk and accelerated COVID-19 vaccine studies for human subjects. The purpose of this review is to contribute to the analysis of vaccine development strategies, vaccine development stages, phase studies and the difficulties, production stages and current status of potential vaccine studies developed to prevent COVID-19.
\end{abstract}

Keywords: COVID-19, vaccine, pandemic

\section{ÖZ}

Yeni patojenik viral suşların ortaya çıkması küresel sağlık için sürekli bir tehdit oluşturmaktadır. En son yeni koronavirüs-2019 (COVİD-19), bunun en iyi bilinen örneğidir. Şiddetli akut solunum yolu enfeksiyonu-koronavirüs-19 virüsünün neden olduğu COVID-19 hızla dünyaya yayılmıştır. Bu salgına karşı ilaç ve aşı çalışmalarının gerçekleştirilmesi ve potansiyel aşı adaylarının hızlı bir şekilde tanımlanması oldukça önemlidir. Sağlıklı yetişkinlerde aday aşıların, hayvan modellerindeki aşı çalışmalarına paralel olarak doğru şekilde değerlendirilmesi ve üretim kapasitesinin büyütülmesi, insan denekler için minimum risk ve hızlandırılmış COVID-19 aşı çalışmalarına fayda sağlayacaktır. Bu derlemenin amacı, aşı geliştirme stratejileri, aşı gelişim aşamaları, faz çalışmaları ile COVİD-19'u önlemeye yönelik geliştirilen aday aşı çalışmalarının güçlükleri, üretim aşamaları ve mevcut durumları hakkında bilgi vererek analiz edilebilmelerine katkı sunmaktır.

Anahtar Sözcükler: COVID-19, aşı, pandemi

\section{Introduction}

In December 2019, a new coronavirus (CoV) pneumonia due to animal-to-human transmission emerged in the local wild animal markets of Wuhan, Hubei province of China, and then the virus started to spread from person to person (Figure 1) (1). nCoV2019, called a new SARS-like CoV (SARS-CoV-2), has spread all over the world and has become a global public health problem over time. The World Health Organization (WHO) stated that the disease agent is a $\mathrm{nCoV}$ and declared the coronavirus disease (COVID-19) as a Public Health Emergency of International Importance on Jan $30^{\text {th }}, 2020$, and then as a pandemic on Mar $11^{\text {th }}, 2020(1,2)$.

CoVs, a large single-stranded RNA virus (+ssRNA) family that can be isolated in different animal species, have gradually become the main pathogens of the respiratory tract disease outbreaks (3). Coronaviruses $(\mathrm{CoVs})$ are viruses with the largest RNA 
genome (about 120 nanometers in size) detected to date. The coronavirus genome, which is a member of the Coronaviridae family, resembles a crown sphere with positive polarity (mRNA), single-stranded, enveloped, 125 nanometer in size, wand-like projections around it (4). CoV ses that affect both humans and animals are divided into four different subgroups, alpha, beta, gamma and delta $\mathrm{CoV}$, based on the sequence identity of the spike (ear of grain) protein or non-structural proteins. Human coronaviruses (HCoV) such as 229E, OC43, NL-63 and HKU1 are highly contagious respiratory viruses responsible for approximately $10-20 \%$ of annual common cold cases. HCoVrelated disease can often cause severe upper and lower respiratory tract infections in the young and elderly population (1). Highly pathogenic CoVs can arise from zoonotic reservoirs (5). It is stated that SARS-CoV-2 is inactivated by ultraviolet (UV) rays or by heating at $56{ }^{\circ} \mathrm{C}$ for 30 minutes, and is sensitive to many disinfectants such as diethyl ether, $75 \%$ ethanol, chlorine, peracetic acid and chloroform. In addition, it has been shown that SARS-CoV-2 is more permanent on plastic and stainless steel than copper and cardboard and can survive more than 72 hours on these surfaces (6).

\section{Mechanism of Action for COVID-19}

The genetic sequence of SARS-CoV-2 is $\geq 70 \%$ similar to SARS-CoV. For this reason, it is stated that the virus uses the same cellular entry receptor Angiotensin-converting enzyme-2 (ACE-2) (7). ACE-2, most commonly found in lung type 2 alveoli, is also expressed by many cells, including glial cells and neurons (8). After SARS-CoV-2 enters alveolar epithelial cells, it proliferates rapidly and triggers a strong immune response. Ultimately, this condition causes cytokine storm and pulmonary tissue damage (7). Cytokine storm is a very important immune system hyperreaction in which cytokine is released into the systemic circulation at a rapid and very high rate. Fever, acute respiratory distress and multiple organ failure develop due to hypercytokinemia, which is called the uncontrolled production of pro-inflammatory cytokines $(7,9)$. SARS-CoV-2 infection reduces the total number of T-cells, CD4+ and CD8+ T-cells, and destroys surviving T-cells functionally (7). In addition, interleukin (IL-6, IL-2, IL-7, IL-10), interferon (INF), tumor necrosis factor (TNF- $\alpha$ ), macrophage and inflammatory protein (MIP1A) levels are high and mostly coagulopathy and diffuse

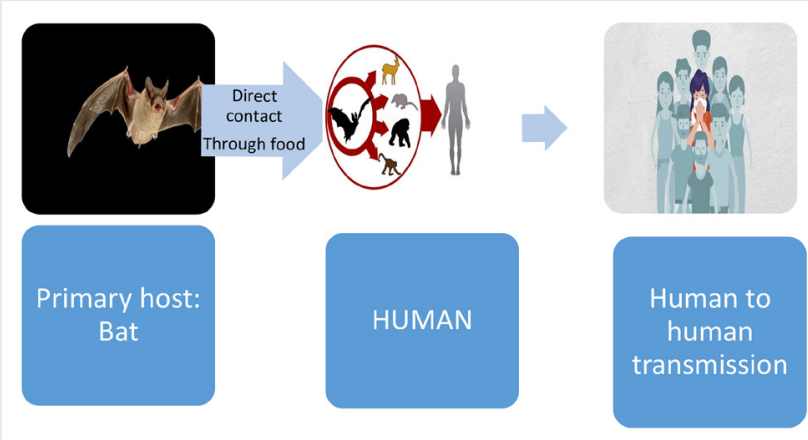

Figure 1. Severe acute respiratory syndrome coronavirus 2 transmission route intravascular coagulation (DIC) develops. In severe cases, microvascular thrombosis and coagulation factors are depleted in DIC that develops as a result of the activation of fulminant coagulation (10).

\section{Viral Immune Response}

The innate immune response is the first line of defense to protect against pathogen (virus, bacteria) infections. Pattern recognition receptors (PRR) produced by immune system cells are used to identify molecules such as double stranded viral RNA pathogen. When viruses infect the host, they multiply in many different cells of the host, settle in different tissues and show high antigenic properties in living organisms. Because of this feature, they generate both humoral and cellular immune response after they enter the organism. This developing immune response depends on the structure of the virus, the way it spreads, and the structural, genetic and biological characteristics of the host. With respect to respiratory viruses, Toll-like receptor (TLR3) 7 and 9 recognize various viral replication products. Each of the TLRs that recognize nucleic acids expressed by macrophages and dendritic cells, which are part of innate immunity, can activate the transcription of genes that induce IFN (lambda interferon). When viral infections develop type 1 IFN expression (usually IFN- $\alpha$, IFN- $\beta$ ) and an innate antiviral defense response occurs. Antiviral activity performed by type I IFNs directly inhibits viral replication. In addition, type 1 IFNs can regulate the cellular immune functions of both natural and adaptive immune systems, and they do this to conserve long-term immunity and maintain resistance to viral infections. Among the three types of IFN, IFN- $\lambda$, one of the Type III IFNs, plays an important role in antiviral immune activities (11).

\section{Immunity Expected as a Result of Viral Vaccines}

The type of vaccines, the size, character and duration of the immune memory are important in providing immunity. T-cells, which are very important in the immune system, express the antigen-recognizing receptors and degenerate while recognizing the antigen. The selection of T-cells in the thymus is governed by the interactions of T-cell receptors. In this case, the selection of $\mathrm{T}$ cells is necessary for the recognition of pathogen-derived antigens (12). One mechanism defined by changes in humoral and cellular vaccine responses is the polymorphism in the major histocompatibility complex genes. Other genetic factors are polymorphisms in PRRs such as TLR or RIG-I like receptors (RLR). In addition, single nucleotide polymorphisms (SNP) in other genes and different expression levels of genes also influence vaccine responses (13). In vaccine studies on coronavirus, SARS$\mathrm{CoV}$ particles inactivated by $\beta$-propiolactone, formalin, UV light or a combination of the two techniques were administered to animals (mice, rabbits) in various ways, and as a result, higher IgG antibody titers were detected as a result of highdose vaccination. In addition, it has been determined that DNA vaccines expressing the SARS-CoV S protein protect against virus replication by inducing humoral and cellular immunity in mice, causing an increase in CD4+ T-cells and creating a stronger antibody response (14). 


\section{Vaccine Definition and Antiviral Vaccine Types}

Vaccines, which have the potential to save life and protect people from the effects of infectious diseases, are biological substances "developed from pathogens or synthetically" that cause disease in order to gain immune memory by creating an immune response and to produce antibodies. The aim of vaccination is to facilitate the rapid response required to prevent disease formation (15).

Antiviral vaccines can be divided into two broad categories.

a. Gene-based vaccines: Gene-based vaccines deliver gene sequences that encode protein antigens that are produced by host cells. These include live-virus vaccines, recombinant vaccine vectors, or nucleic acid vaccines.

b. Protein-based vaccines: These vaccines include fully inactivated virus, individual viral proteins or subdomains, or viral proteins that are all assembled as particles all produced in vitro. Recombinant vaccine vectors and nucleic acid vaccines are best suited for speed because they can be more easily adapted to platform production technologies where upstream supply chains and downstream processes are the same for each product (16).

\section{Vaccine Development Strategies}

One of the important goals in vaccine development is to determine the immune response that should be elicited by the vaccine. Antibody mediated neutralization has traditionally been the main target of vaccines. Because many pathogens require receptor-mediated binding to cells and/or fusion, or mediate pathogenicity by producing specific toxins. These can all represent protective antibody targets. New vaccines targeting more complex pathogens are designed to enhance other aspects of innate and adaptive response. The relative contribution of antibodies, CD4+ and CD8+ T-cells and the innate immune process to protection from infections should be evaluated and then transferred to vaccine-induced primary immunity. Vaccines need to be produced efficiently and administered in a manner acceptable to the recipient. In the earliest vaccines, either living (attenuated versions of the pathogen or organisms capable of causing cross-reactive immunity but less virulent without inducing disease) or dead all organisms were used. All organisms have the advantage of being highly immunogenic and typically stimulate a response similar to that produced by natural infection. However, they can also produce the pathology caused by natural infection (17).

Vaccines can take a long time to make and distribute, and ensuring adequate supply worldwide is another challenge. One of the most challenging aspects of vaccine design is continuing to evaluate the effectiveness/efficacy of new vaccine formulations. The road to licensure involves understanding the biology and immunology of host-pathogen interactions. For this, immunological criteria, the nature of the vaccine formulation, its relationship with the antigens selected to maintain the specific immune response, the evaluation of immune responses, and testing in animal models and humans are aimed. Evaluating whether adjuvants are necessary to enhance the immune response to the vaccine antigen is a key decision. Likewise, the ability to develop a scalable, robust and repeatable formulation suitable for production is critical to a successful license. Facilities are required for the production and packaging of the vaccine. Proper storage of vaccines and monitoring at administration sites is critical because improper storage can render the vaccine to a non-immunogenic vaccine or potentially harmful (18).

\section{Vaccine Development Stages}

Combining the correct antigens and adjuvants to optimize the adaptive immune response is essential in the development of any new vaccine, and the production of vaccine antigens should be practically feasible (17). The time required for a vaccine to be produced and distributed varies by product and type of vaccine. Production can be relatively simple or more complex. Additional studies such as determination of viability and shelf life for live attenuated vaccines are required. From the moment the raw materials are supplied, it may take 10-26 months for vaccines to be ready for shipment. Thanks to technological developments, it is possible to accelerate these stages, but it is possible to return to the beginning after a mistake and extend the time. Continuous monitoring of efficacy and safety in vaccinated populations is essential to maintain confidence in vaccine programs (18). The development of any new vaccine includes the following stages (17).

Life cycle of the pathogen and epidemiology: Knowledge of pathogen structure, route of entry, interaction with cellular receptors, replication sites and disease-causing mechanisms are important to identify appropriate antigens for disease prevention. Demographic characteristics of the infection, specific risk groups, and age-specific infection rates determine which population will be vaccinated at what age.

Immune control and escape: Interactions between host and pathogen are investigated by determining the relative importance of antibodies, different types of T-cells and innate immunity, immune escape strategies during infection, and possible immune relationships of protection. This information guides the specific immune response required for protection, as well as the identification and selection of the antigen.

Antigen selection and vaccine formulation: The selected antigen can be formulated so that it remains suitably immunogenic and stable over time, elicits a potentially protective immune response, and is also ultimately amplified for commercial production.

Vaccine preclinical and clinical testing: The candidate vaccine must be tested for immunogenicity, safety and efficacy in preclinical and appropriately designed clinical trials (17). Studies of the phase until the vaccine is put on the market are given (Table 1) (18).

Vaccines are the most effective and economical way to prevent and control infectious diseases (19). Due to the human and economic effects of COVID-19, it has become necessary to evaluate new generation vaccine technology platforms and to accelerate the vaccine development studies against this pandemic (20). Rapid vaccine development is a global imperative to 
prevent COVID-19. A higher level of community immunity can be achieved thanks to the pandemic ability of viruses to spread. However, this may happen with recurrent waves of infection in the next few years until an effective vaccine against SARS$\mathrm{CoV}-2$ is found or approximately $60-70 \%$ of people develop immunity. The consequences of recurrent outbreaks may result in unacceptably high mortality and serious economic losses, and ultimately necessitate major changes in human lifestyle. It is therefore imperative to ensure access to approved vaccines available for large-scale distribution over the next 1-2 years (16).

Since the world has not yet developed a vaccine or drug against COVID-19, it is trying to gain time and immunity by delaying the spread of the disease (21). While new outbreaks from newly emerging viruses are inevitable, scientists, epidemiologists and the healthcare industry continue to develop vaccines and antivirals using global viral surveillance programs and race new technologies to minimize and control the epidemic (1).

\section{COVID-19 Current Vaccine Strategies}

SARS-CoV-2 viral RNA encodes various proteins, including four structural proteins whose potential targets are Spike (S), Envelope (E), Membrane (M), and Nucleocapsid (N) (17) (Figure 2) (22). CoV S protein is the main envelope glycoprotein and is the main determinant of protective immunity. The $S$ protein consists of two basic subunits, S1 and S2. S1 directs receptor binding while S2 is responsible for membrane fusion. Due to the high selective pressure and tropism determinants, the $S$ protein is the most diverse region of CoV. This diversity poses a major challenge to the progress of vaccine development. Surface glycoproteins are the main target for vaccine development (1). The $S$ protein is the outermost part of the virion that shows high glycosylation among the surface proteins of $\mathrm{CoV}$ on the envelope. In addition, it is an important structural protein that allows the virus to attach to the specific cell and enter the host cell (23). One of the main targets of $\mathrm{CoV}$ vaccines in humans is to elicit a strong humoral immune response against the $S$ protein (1). It is stated that 12-18 months may be required for the development of a producible, safe and effective vaccine for COVID-19 (24). MERS-CoV-specific CD4+ and CD8+ T cells, learned from previous MERS-CoV infection, were detected in mononuclear blood cells of infected individuals. Therefore, the balance of $\mathrm{T}$ and $\mathrm{B}$ cell responses has often been considered the gold standard for preventing and resolving MERS-CoV and SARS-CoV infection (1). Hyperimmunoglobulin isolated from the sera of recovered patients who produce high antibody titers may provide passive immunity against SARS-CoV-2. It is stated that antibody-dependent therapy may represent the most effective, short-term therapeutic intervention, if $S$ protein targeting, regulatory and safety requirements can be addressed (24). Since the $\mathrm{S}$ proteins between SARS-CoV and SARS-CoV-2 show only $76-78 \%$ sequence similarity, it reduces the likelihood that existing test vaccines and antivirals will protect against SARS-CoV-2 (1).

Rapid diagnosis, vaccines and therapeutics are extremely important interventions for COVID-19 pandemic management (25). Many countries, companies and institutions share their COVID-19 action programs and their developments in vaccine development against this virus with the world. Today, many of

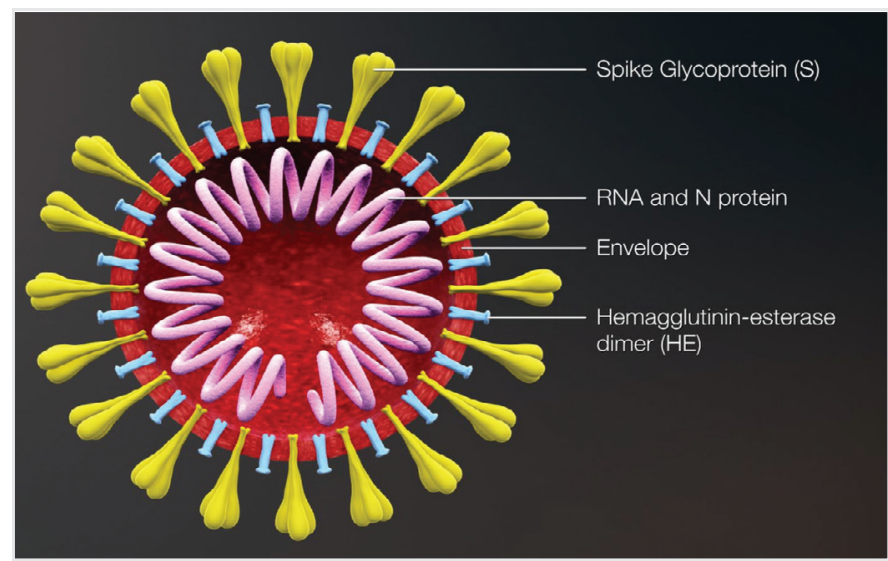

Figure 2. Coronavirus cross section

\section{Table 1. Vaccine Phase Studies}

Phase-1 studies

Phase-2 studies

Phase-3 studies

Phase-4 studies
In this phase, the aim is to collect the initial safety and immunogenicity data of the vaccines and these individuals, typically containing $<100$ volunteers, are healthy individuals.

These studies are also used for dose and sometimes program optimization.

These studies typically involve 100 volunteers in the targeted patient population.

In this phase, it is aimed to verify the dose amount, frequency and route of administration, to create immunogenicity data in the target population, to collect additional safety data and, if possible, to show "proof of concept" from the immunogenicity and/or efficacy endpoints.

Phase-3 studies, known as registration, typically involve 1,000 volunteers in the target population. It frequently includes randomized control trials in which recipients are placed in actively vaccinated groups.

These large sample sizes are used to adequately address the immune response, efficacy, and reactogenicity of the candidate vaccine.

These studies could also examine the immunity and safety profile of the candidate vaccine when administered with other vaccines routinely administered to the target population.

In parallel with Phase-3 clinical development, pilot-scale manufacturing progresses to full-scale production, including production of vaccine lots, and clinical testing to verify manufacturing consistency, and then Phase- 4 is reached and the vaccine is released and licensed. 
the vaccines studied against COVID-19 are in the design and preparation phase, but there are some vaccines whose effectiveness was evaluated in the first clinical studies and in animals (26).

\section{COVID-19 Candidate Vaccine Production Studies}

Since there is no coronavirus vaccine in the market and there is not yet a large-scale production capacity for these vaccines, these processes and capacities must first be established. Doing this for the first time can be tedious and time consuming $(27,28)$. But the biggest challenge of vaccine and antiviral development is the elusive nature of viruses that often arise from populations of highly heterogeneous virus strains circulating in animal reservoirs. The evolutionary dynamics of RNA viruses are complex and their high mutation rates, fast replication kinetics, and large population sizes pose major challenges for traditional population genetics (21). There is no approved $\mathrm{HCoV}$ vaccine so far. The development of vaccines that can be applied to humans can take years, especially since their safety needs to be tested in detail and superior new technological applications are required for serial production (29). The Coalition for Epidemic Preparedness Innovations (CEPI) has funded a large number of innovative researchers in the field, and these researchers are seriously working to develop the SARS-CoV-2 vaccine. However, none of these companies and institutions have an established drug development pipeline and the capacity to produce the required number of doses to bring such a vaccine to late-stage clinical trials that allow for licensing. An mRNA-based vaccine that expresses the target antigen in vivo after injection of mRNA encapsulated in lipid nanoparticles developed jointly by Moderna and the Vaccine Research Center of the National Institutes of Health is currently the furthest step. CureVac is also working on a similar vaccine, even though it is still in the preclinical stage. Additional approaches in the pre-clinical phase include recombinant-proteinbased vaccines (ExpresS2ion, iBio, Novavax, Baylor College of Medicine and Sichuan Clover Biopharmaceuticals), viral-vectorbased vaccines (Vaxart, Geovax, Oxford University and Cansino Biologics), DNA vaccines (Inovio and Applied DNA Sciences), live attenuated vaccines (Serum Institute and Codagenix) and inactivated virus vaccines (Table 2) (27). Inactivated vaccines are an important traditional vaccine type that can be easily produced and developed quickly. In this approach, SARS-CoV-2 virions can be chemically and/or physically inactivated to elicit neutralizing antibodies. In studies of SARS-CoV and MERS$\mathrm{CoV}$, neutralizing antibodies have been successfully and robustly induced by an inactivated vaccine in all animal experiments, but still need testing as there are concerns about the development of antibody-related viral infection and other safety issues. Other alternative vaccine approaches requiring further research and testing in animals, including live attenuated vaccines, subunit vaccines and vectored vaccines, should also gain momentum $(27,28)$.

All these platforms have advantages and disadvantages, and it is impossible to predict which strategy will be faster or more successful. Johnson \& Johnson (J\&J) and Sanofi have recently participated in SARS-CoV-2 vaccine development. While J\&J uses an experimental adenovirus vector platform that has not yet resulted in a licensed vaccine, the Sanofi vaccine is planned to be made using a process similar to that used for the approved Flublok recombinant influenza virus vaccine, but they estimate that it will result in human readiness within months (27).

Table 2. Overview of Vaccine Production Platforms and Technologies for SARS-CoV-2.

\section{SARS-CoV-2 Vaccines: Various Approaches}

All vaccines aim to expose the body to an antigen that does not cause the disease, but if a person becomes infected it causes an immune response that can block or kill the virus. There are at least eight types of vaccines being tested against $\mathrm{CoV}$. These types of vaccines consist of different viruses or viral parts, such as genetically modified measles and adenovirus (30).

Viral vaccines: These vaccines are developed using the virus itself, in a weakened or inactivated form. There are at least seven teams involved in developing virus vaccines. Many of the current vaccines, such as those against measles and polio, are made this way, but they require extensive safety testing. Looking at examples from around the world about virus vaccines; Sinovac Biotech in Beijing has begun testing an inactive version of SARSCoV-2 in humans (30). Again, researchers at the University of Hong Kong continue to work on vaccine development by weakening the influenza virus in virus vaccine studies. molecular clamp technology. This polypeptide retains the twisted $S$ protein so that the body's immune system recognizes it before the virus is activated (31).

Viral vector vaccines: There are about 25 groups reporting that they are working on viral vector vaccines. A virus such as measles or adenovirus was genetically engineered to produce $\mathrm{CoV}$ proteins in the body. There are two types of these viruses: those that can still reproduce inside cells, and those that cannot cause disease because key genes are disabled (30). Over the past century, outbreaks have been successfully controlled thanks to vaccines (cholera, typhoid, polio, measles, plague, tetanus) developed using various technologies, mainly with classical pathogen inactivation or attenuation (32). Companies (Sanofi and GlaxoSmithKline) have collaborated and have been continuing their work rapidly for recombinant vaccines that use genetic technology for the treatment of COVID-19 (33). Viral vector vaccines are vaccines produced using recombinant DNA technology, and this vaccine type studies continue intensively. It can be classified into two main categories: DNA vaccines and recombinant (protein subunit) vaccines. DNA vaccines consist of synthetic DNA containing the gene encoding the disease-agent protein. Recombinant (protein subunit) vaccines are vaccines that contain a small part of the microorganism rather than the whole one. Hepatitis B vaccine is an example (34). When viral vector vaccine studies are analyzed; Novavax uses recombinant protein nanoparticle technology that presents viral $S$ protein-derived antigen in vaccine development. Pasteur Institute (France), on the other hand, continues to work against the SARS-CoV-2 virus by adapting the vectorial measles virus. In addition, Oxford University (England) tested the ChAdOx1 $\mathrm{nCoV}-19$ vector vaccine funded by CEPI. This vaccine was 
tested on animals at the beginning of March and Phase 1 and Phase 2 trials were started in 510 volunteers at the end of March. CanSino Biologics (China) conducted a Phase 1 safety trial in Wuhan on 18 March in 108 volunteers to test the recombinant adenovirus vaccine candidate $\mathrm{Ad} 5-\mathrm{nCoV}$, and a Phase 2 trial on 500 volunteers on April 12 (31). The Dokuz Eylul University in Turkey (İzmir), spike protein recombinant vaccine development continues to work against and ACE-2 receptor (35).

Nucleic acid vaccines: These vaccines aim to use genetic instructions (in the form of DNA or RNA) for a coronavirus protein that causes an immune response. There are at least 20 teams working on nucleic acid vaccines. Most of these vaccines encode the spike protein of the virus, and then the nucleic acid that makes copies of the virus protein is introduced into human cells (30). There are many major biotechnologies that have advanced nucleic acid vaccine platforms for COVID-19. For example, INOVIO Pharmaceuticals is developing a DNA vaccine, while others such as Moderna Therapeutics and CureVac are researching RNA vaccine platforms (36-38). The candidate vaccine from Moderna is an RNA vaccine developed using technology that is faster, cheaper, and easier to scale than traditional vaccine methods. The vaccine promises to be more reliable as it is not produced by weakening living viruses, but based on a synthetic RNA molecule encoding a single viral protein. CureVac is also working against the mRNA-based SARS-CoV-2 virus. In addition, vaccination studies are accelerating to allow human trials in parallel with animal trials due to the pandemic. Based on the positive results of the INO-4800 DNA vaccine developed by Inovio Pharmaceuticals (USA), it was allowed to be tested in the Phase 1 clinical phase in 40 volunteers and the first dose in humans was administered on April 6 (31). In Turkey, Ankara University (Ankara) carries out DNA and peptide vaccine development studies against COVID-19. Again, the first step of DNA vaccination studies carried out by Ege University (İzmir) has been completed and the second phase has been started (35).

Table 2. Overview of Vaccine Production Platforms and Technologies for SARS-CoV-2

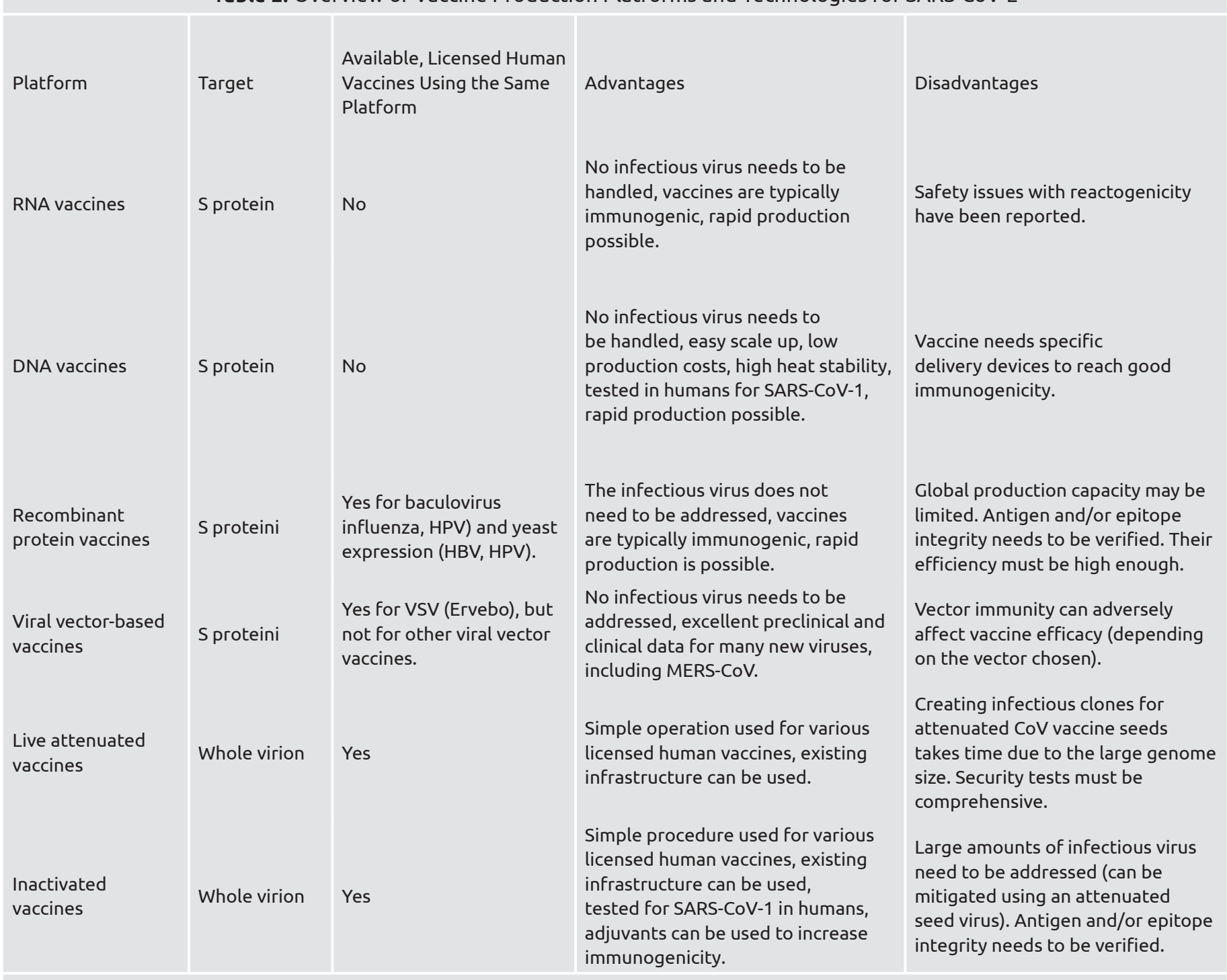

HBV: Hepatitis B Virus, HPV: Human papilloma virüs, MERS-CoV: Middle east respiratory syndrome coronavirus, SARS-CoV: Severe acute respiratory syndrome coronavirus 


\section{Conclusion and Recommendations}

Three pandemics caused by SARS, MERS, and SARS-CoV-2 are believed to have started as a result of bat coronaviruses that crossed the species barrier. Therefore, other outbreaks are likely to occur in the future due to the unlimited supply of coronavirus available in the bat population. Prevention is always the best treatment, and continuous viral surveillance of wild animals is extremely important for potentially emerging CoVs. Clinical trials begin with small safety studies in animals and humans, followed by much larger studies to determine whether a vaccine induces an immune response. As a result of all these, it may take many years for the vaccine to emerge, so fast, reliable and easy-touse viral test kits should be developed on the research side. The continuous development of vaccines and antivirals will provide an assurance of fighting and controlling emerging $\mathrm{CoV}$ diseases.

Peer-review: Externally peer-reviewed.

\section{Authorship Contributions}

Concept: S.H., A.K., Design: S.H., A.K., Data collecting or Processing: S.H., A.K., Analysis or Interpretation: S.H., A.K., Literature Search: S.H., A.K., Writing: S.H., A.K.

Conflict of Interest: No conflict of interest was declared by the authors.

Financial Disclosure: The authors declared that this study received no financial support.

\section{References}

1. Tse LV, Meganck RM, Graham RL, Baric RS. The Current and Future State of Vaccines, Antivirals and Gene Therapies Against Emerging Coronaviruses. Front Microbiol 2020;11:658.

2. World Health Organization Press Conference 2020 The World Health Organization (WHO) Has Officially Named the Disease Caused by the Novel Coronavirus as COVID-19. Last Accessed Date:12.05.2020. Available from: https://www.who.int/docs/defaultsource/coronaviruse/situation-reports/20200312-sitrep-52-covid-19. pdf?sfvrsn=e2bfc9c0_4.

3. Cascella M, Rajnik M, Cuomo A, Dulebohn S, Napolli R. Features, Evaluation and Treatment Coronavirus (COVID-19); Stat Pearls Publishing: Treasure Island, FL, USA: 2020.

4. Fehr AR, Perlman S. Coronaviruses: An Overview of Their Replication and Pathogenesis. Methods in Molecular Biology (Clifton, N.J.) 2015;1282:1-23.

5. Raj VS, Osterhaus AD, Fouchier RA, Haagmans BL. MERS: Emergence of a Novel Human Coronavirus. Curr Opin Virol 2014;5:58-62.

6. Jin Y, Yang H, Ji W, Wu W, Chen S, Zhang W, Duan G. Virology, Epidemiology, Pathogenesis, and Control of COVID-19. Viruses 2020;12:372.

7. Li H, Liu SM, Yu XH, et al. Coronavirus Disease 2019 (COVID-19): Current Status and Future Perspective. Int J Antimicrob Agents 2020;55:105951.

8. Baig AM, Khaleeq A, Ali U, Syeda H. Evidence of the COVID-19 Virus Targeting the CNS: Tissue Distribution, Host-Virus
Interaction, and Proposed Neurotropic Mechanisms. ACS Chemical Neuroscience 2020;11:995-8.

9. Tisoncik JR, Korth MJ, Simmons CP, Farrar J, Martin TR, Katze MG. Into the eye of the cytokine storm. Microbiol Mol Biol Rev 2012;76:16-32.

10. Chen N, Zhou M, Dong X, Qu J, Gong F, Han Y, et al. Epidemiological and clinical characteristics of 99 cases of 2019 novel coronavirus pneumonia in Wuhan, China: A descriptive study. Lancet 2020;395:507-13.

11. Zhou JH, Wang YN, Chang QY, Ma P, Hu Y, Cao X. Type III Interferons in Viral Infection and Antiviral Immunity. Cell Physiol Biochem 2018;51:173-85.

12. Rouse BT, Lukacher AE. Some unmet challenges in the immunology of viral infections. Discovery Med 2010;10:363-70.

13. Zimmermann P, Curtis N. Factors That Influence the Immune Response to Vaccination. Clin Microbiol Rev 2019;32:e0084-18.

14. Broadbent AJ, Boonnak K, Subbarao K. Respiratory Virus Vaccine. Mucosal Immunology 2015:1129-70.

15. Gül B, Dikmen BY. Aşı Adjuvanları ve İstenmeyen Etkileri. Veteriner Farmakoloji ve Toksikoloji Derneği Bülteni 2019;10:91-105.

16. Graham BS. Rapid COVID-19 Vaccine Development. Science 2020;368:945-6.

17. Cunningham AL, Garçon N, Leo O, Friedland LR, Strugnell R, Laupèze B, et al. Vaccine development: from concept to early clinical Testing. Vaccine 2016;34:6655-64.

18. Preiss S, Garçon N, Cunningham AL, Strugnell R, Friedland LR. Vaccine provision: delivering sustained \& widespread use. Vaccine 2016;34:6665-71.

19. Remy V, Largeron N, Quilici S, Carroll S. The economic value of vaccination: why prevention is wealth. Value Health 2015;17:450.

20. Le TT, Andreadakis Z, Kumar A, Roman RG, Tollefsen S, Saville M. et al. The COVID-19 Vaccine Development Landscape. Nature Reviews Drug Discovery 2020;19:305-6.

21. Lauring AS, Andino R. Quasispecies theory and the behavior of RNA viruses. PLoS Pathogens 2010;6:1-8.

22. Why the Coronavirüs and Most Other Viruses Have No Cure. Last Accessed Date: 12.06. 2020. Available from: https://www. inquirer.com/health/coronavirus/coronavirus-covid19-antiviral-cureantibiotic-20200318.html

23. Guo YR, Cao QD, Hong ZS. The Origin, transmission and clinical therapies on coronavirus disease 2019 (COVID-19) outbreak-an update on the Status. Mil Med Res 2020;7:1-10.

24. Osman EEA, Toogood PL, Neamati N. COVID-19: Living through another pandemic. ACS Infect Dis 2020;6:1548-52.

25. Pang J, Wang MX, Ang I, Tan SHX, Lewis RF, Chen JIP, et al. Potential rapid diagnostics, vaccine and therapeutics for 2019 novel coronavirus (2019-nCoV): A systematic review. J Clin Med 2020;9:623.

26. Zhang J, Zeng H, Gu J, Li H, Zheng L, Zou Q. Progress and prospects on vaccine development against SARS-CoV-2. Vaccines 2020;8:153.

27. Amanat F, Krammer F. SARS-CoV-2 vaccines: status report. Immunity 2020;52:583-9. 
28. Yuen KS, Ye ZW, Fung SY, Chan CP, Jin DY. SARS-CoV-2 and COVID-19: The most important research questions. Cell Biosci 2020;10:1-5.

29. Sağlık Bakanlığı 2020 COVID-19 Yeni Koronavirüs Hastalığı. Last Accessed Date: 12.05.2020. Available from: https://covid19bilgi. saglik.gov.tr/tr/sss/halka-yonelik.html

30. Callaway E. The Race for coronavirus vaccines: a graphical guide. Nature 2020;580:576-7.

31. Editorial. Race for a COVID-19 Vaccine. Science Direct 2020;55:102817.

32. Kim YC, Dema B, Reyes-Sandoval A. COVID-19 Vaccines: Breaking Record Times to First-in-Human Trials. npj Vaccines 2020;5:1-3.

33. GSK 2020 GSK actions to support the global response to COVID-19. Last Accessed Date: 12.05.2020. Available from: https://www.gsk. $\mathrm{com} / \mathrm{en}$-gb/media/press-releases/sanofi-and-gsk-to-join-forces-inunprecedented-vaccine-collaboration-to-fight-covid-19/
34. Aytar M, Başbülbül G. Rekombinant Aşılar. Elektronik Mikrobiyoloji Derg 2019;17:1-10.

35. COVID-19 Türkiye Web Portalı 2020. Last Accessed Date: 12.05.2020. Available from: https://covid19.tubitak.gov.tr/ duyurular/covid-19-turkiye-platformu-asi-ve-ilac-gelistirme

36. INOVIO 2020 Urgently Focused on Developing Covid-19 Vaccine Because the World Can't Wait. Last Accessed Date: 12.05.2020. Available from: https://www.inovio.com/our-focus-serving-patients/ covid-19/

37. Smith J. 2020 Curevac Bids to Develop First mRNA Coronavirus Vaccine. Available from: https://www.labiotech.eu/medical/curevaccoronavirus-outbreak-cepi/

38. Park A. Inside the company that's hot-wiring vaccine research in the race toc ombat the coronavirus 2020 Time. Last Accessed Date: 12.05.2020. Available from: https://time.com/5775784/coronavirusvaccine-research/ Erişim Tarihi: 12.05.2020. 